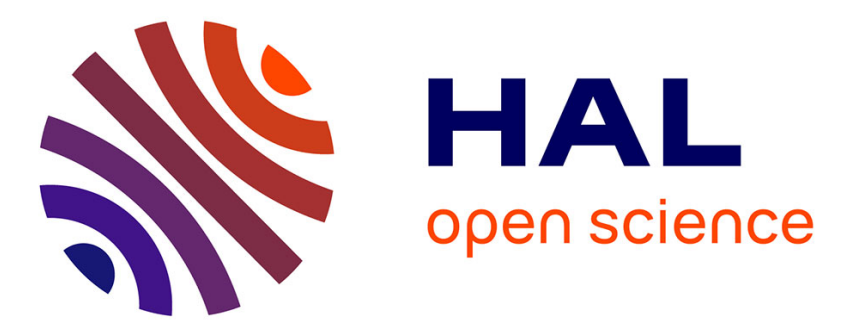

\title{
Improvement of the quadratic non-linear optical properties of pyrimidine chromophores by N-methylation and tungsten pentacarbonyl complexation
}

Sylvain Achelle, Samia Kahlal, Alberto Barsella, Jean-Yves Saillard, Xiaoyang

Che, Julien Vallet, Filip Bureš, Bertrand Caro, Françoise Robin-Le Guen

\section{To cite this version:}

Sylvain Achelle, Samia Kahlal, Alberto Barsella, Jean-Yves Saillard, Xiaoyang Che, et al.. Improvement of the quadratic non-linear optical properties of pyrimidine chromophores by Nmethylation and tungsten pentacarbonyl complexation. Dyes and Pigments, 2015, 113, pp.562-570. 10.1016/j.dyepig.2014.09.028 . hal-01088697

\section{HAL Id: hal-01088697 https://hal.science/hal-01088697}

Submitted on 9 Jan 2015

HAL is a multi-disciplinary open access archive for the deposit and dissemination of scientific research documents, whether they are published or not. The documents may come from teaching and research institutions in France or abroad, or from public or private research centers.
L'archive ouverte pluridisciplinaire HAL, est destinée au dépôt et à la diffusion de documents scientifiques de niveau recherche, publiés ou non, émanant des établissements d'enseignement et de recherche français ou étrangers, des laboratoires publics ou privés. 
1

\section{Improvement of the quadratic non-linear optical properties of pyrimidine chromophores by $N$ - methylation and tungsten pentacarbonyl complexation.}

Sylvain Achelle, ${ }^{1 *}$ Samia Kahlal, ${ }^{2}$ Alberto Barsella, ${ }^{3}$ Jean-Yves Saillard, ${ }^{2}$ Xiaoyang Che, ${ }^{2}$ Julien Vallet, ${ }^{2}$ Filip Bureš, ${ }^{4}$ Bertrand Caro, ${ }^{1}$ and Françoise Robin-le Guen. ${ }^{1}$

${ }^{1}$ Institut des Sciences Chimiques de Rennes UMR CNRS 6226, IUT de Lannion, rue Edouard Branly, BP 30219, F22302 Lannion Cedex, France

${ }^{2}$ Institut des Sciences Chimiques de Rennes UMR CNRS 6226, Campus de Beaulieu, 263 av. du Général Leclerc, 35042 Rennes, France

${ }^{3}$ Département d'Optique ultra-rapide et Nanophotonique, IPCMS-CNRS, 23 Rue du Loess, BP 43, 67034 Strasbourg Cedex 2, France

${ }^{4}$ Institute of Organic Chemistry and Technology, Faculty of Chemical Technology, University of Pardubice, Studentská 573, Pardubice, 53210, Czech Republic.

Corresponding author: sylvain.achelle@univ-rennes1.fr Tel: + 33 (0)2 96469448 Fax : + 33

(0)296469354 


\begin{abstract}
In this contribution, we report the synthesis of two series of compounds: 4-(arylvinyl)-1methylpyrimidinium derivatives and tungsten pentacarbonyl complexes of 4(arylvinyl)pyrimidines. Their second order non-linear properties, measured by Electric-Field Induced Second Harmonic generation (EFISH) method, and their photophysical behavior were thoroughly investigated and compared to the corresponding 4-(arylvinyl)pyrimidines. A strong enhancement of the NLO response was observed upon methylation or complexation by $\mathrm{W}(\mathrm{CO})_{5}$ of the pyrimidine ring. DFT theoretical calculations were performed to provide complementary insights on the structure-properties relationships in particular concerning the amplitude of the NLO response.
\end{abstract}

Key words: Pyrimidine, Internal Charge Transfer, Push-Pull chromophores, Tungsten Pentacarbonyl Complexes, Non-linear Optics, Theoretical calculations

\title{
1. Introduction
}

Compounds with second-order nonlinear optical (NLO) properties are important as molecular building block materials for optical communications, optical data processing and storage or electro-optical devices [1]. The most widely studied second order (quadratic) NLO effects such as second harmonic generation (SHG) arise from high first molecular hyperpolarizabilities $\beta$. The typical design of molecules presenting large $\beta$ values consists in dipolar molecules (D- $\pi$-A) also called push-pull. The D- $\pi$-A molecules possess an electrondonating (D) and an electron-withdrawing (A) groups linked through a $\pi$-conjugated spacer which provides the molecule an internal charge transfer (ICT) upon excitation.

Pyrimidine, which is a highly $\pi$-deficient aromatic heterocycle, can therefore be used as electron withdrawing part in push-pull molecules [2]. Moreover, the ICT along the molecule backbone can also induce luminescence properties. The ability of protonation, hydrogen bond 
formation and chelation of the nitrogen atoms of the pyrimidine ring are also of great importance and, therefore, such derivatives could be used for the formation of supramolecular assemblies and as sensors. The pyrimidine ring was also largely used in the structure of twophoton absorption (TPA) chromophores and 4,6-di(arylvinyl)pyrimidines have become a well-established TPA chromophore design [3]. Some quadratic NLO chromophores incorporating pyrimidine fragment were also described [4]. During the past decade, some of us have described a large library of pyrimidine derivatives presenting ICT [5]. In particular we have described the synthesis and the quadratic NLO response of a series of 4(arylvinyl)pyrimidines [6]. Recently, the NLO properties of the same compounds have been subjected to theoretical investigation by another team [7].

Two design strategies have been described for increasing the second-order NLO polarizability of push-pull molecules [8]. The first one consists in the elongation of the conjugation pathway. The second one consists in increasing the strength of the donor and/or the acceptor. In this context, using the nitrogen lone electron pair of electron-withdrawing azaheterocycle, either by protonation, $N$-alkylation $/ N$-arylation or complexation, is an interesting strategy. We have already demonstrated that the protonation of the nitrogen atoms of pyrimidine push-pull derivatives lead to an increased ICT as shown by the bathochromic shifts observed in UV-vis spectra [5c, 5e,f, 6]. Recently, Cariati and coworkers described pH-triggered pyridine based NLO switch [9]. N-Alkylation and $N$-arylation were efficiently applied on pyridine and benzothiazole derivatives in particular by the working groups of Clays and Vaquero [10]. Finally, another way to increase the electron attracting strength of azaheterocycles consists in complexation of their nitrogen lone electron pair by a transition metal and some metal carbonyl based NLO chromophores have already been described [11]. To the best of our knowledge, none of these strategies have been tested on pyrimidine NLO chromophores. 
As a continuation of our research interest in the synthesis of heterocyclic second-order NLO chromophores $[4 \mathrm{~b}, 6,12]$, we focus herein on exploration of $N$-methylated pyrimidinium and tungsten pentacarbonyl pyrimidine complex and to compare their secondorder NLO response with previously described pyrimidine derivatives. Experimental data are supported by DFT/TD-DFT theoretical analysis.

\section{Results and Discussion}

\subsection{Synthesis}

Starting from already described 4-(arylvinyl)pyrimidines 1-4 [6], tungsten pentacarbonyl complexes 5-8 were obtained according to the procedure described on pyridine derivatives [13] (Scheme 1). The complexation reaction is regiospecific, probably due to steric reasons and the new complexes 5-8 were obtained in good yields.

\section{$<$ Scheme 1 $>$}

The $N$-methylation of compounds $\mathbf{2}$ and $\mathbf{4}$ was carried out with iodomethane at reflux without solvent. As described in the literature [14], $N$-methylation occurs regioselectively on the diazine rings and methylated derivatives $\mathbf{9}$ and $\mathbf{1 0}$ were obtained in good yields (Scheme 2). It should be noted that this strategy is not applicable on dimethylamino derivatives $\mathbf{1}$ and $\mathbf{3}$ : methylation of the amino group is observed in addition to the methylation of the pyrimidine ring. A reversal strategy in which the methylation step was carried out before the condensation has been tested. However when using similar conditions, the methylation of 4methylpyrimidine is not regioselective and led to a mixture of 1,4-dimethyl-pyrimidin-1-ium and 3,4-dimethyl-pyrimidin-3-ium in 8/2 ratio.

$<$ Scheme 2>

All new compounds are soluble in THF, chloroform and dichloromethane and were characterized using a variety of analytical techniques. NMR experiments proved very useful 
to confirm the structures of the compounds (see Experimental Section and Supporting Information). The stereochemistry of the double bonds was unequivocally established on the basis of the coupling constant for the vinylic protons in the ${ }^{1} \mathrm{H}$ NMR spectra $(\mathrm{J} \approx 16 \mathrm{~Hz})$.

These materials are perfectly stable in the solid state and could be stored without the need for special precautions.

\subsection{Linear optical properties}

The UV-Vis and photoluminescence (PL) spectroscopic data of compound 1-10 measured in dichloromethane at $25^{\circ} \mathrm{C}$ are presented in table 3. Analyses have been carried out using low concentration solutions $\left(1.0 \times 10^{-5}\right.$ to $3.0 \times 10^{-5} \mathrm{M}$ for UV/Vis spectra and $1.0 \times 10^{-6}$ to $3.0 \mathrm{x}$ $10^{-6} \mathrm{M}$ for PL spectra). Under these conditions, self-absorption effects were not observed. All compounds are photostable and did not undergo cis-trans isomerization under the analysis conditions. As an example, the absorption spectra for derivatives 2, 6 and 9 are shown in Figure 1.

\section{$<$ Figure 1 $>$}

As expected the complexation and more importantly the methylation of chromophores 1-4 led to a red shift of their absorption band. Whereas compound 1-4 are fluorescent, tungsten derivatives 5-8 and methylated compounds $\mathbf{9}$ and $\mathbf{1 0}$ are completely non-emissive. Biphenylenevinylene derivatives exhibit blue shifted absorptions in comparison to their phenylenevinylene analogues. On the other hand biphenylenevinylene derivatives $\mathbf{3}$ and $\mathbf{4}$ are red-shifted in emission when compared to $\mathbf{1}$ and $\mathbf{2}$ respectively.

In order to study the ionic character of methylpyrimidinium derivative $\mathbf{9}$, an absorption solvatochromic study was performed (Figure 2, Table 2). Pyrimidinium derivative 9 showed absorption maxima of about $500 \mathrm{~nm}$ in nonpolar $n$-heptane and dipolar/protic solvents such as acetonitrile, DMSO and methanol and the most bathochromically shifted CT-bands were 
observed in polarizable dichloromethane/chloroform (550 and $545 \mathrm{~nm}$ ). This observation implies that the excited state can be effectively stabilized by polarizable halogenated solvents. These results are in contrast to standard behavior of D- $\pi$-A molecules [5c-f, 6] and can be attributed to ionic structure of 9 [15]. The impact of the ionic structure of 9 can be further demonstrated by the observed blue shift of the absorption band in $\mathrm{CH}_{2} \mathrm{Cl}_{2}$ solution with increasing its concentration indicating aggregation (Table 3). Similar behavior was observed for compound $\mathbf{1 0}$ (Figure S69, Tables S70-S71)

\section{$<$ Figure 2 $>$ \\ $<$ Table 2> \\ $<$ Table 3>}

\subsection{Second order $N L O$ properties}

Second-order non-linear properties were studied in $\mathrm{CHCl}_{3}$ solution using the electric-fieldinduced second-harmonic generation technique (EFISH), which provides information about the scalar product $\mu \beta(2 \omega)$ of the vector component of the first hyperpolarisability tensor $\beta$ and the dipole moment vector [16]. This product is derived according to equation 1 and considering $\gamma_{0}(-2 \omega, \omega, \omega, 0)$, the third-order term, as negligible for the push-pull compounds under consideration. This approximation is usually used for push-pull organic and organometallic molecules.

$$
\gamma_{\mathrm{EFISH}}=\mu \beta / 5 \mathrm{kT}+\gamma_{0}(-2 \omega, \omega, \omega, 0)
$$

\section{Equation 1}

Measurements were performed at $1907 \mathrm{~nm}$, obtained from a Raman-shifted Nd:YAG ${ }^{+}$laser source, which allowed us to work in conditions far from the resonance peaks of the compounds we were investigating (1-10). It should be noted that the sign and values of $\mu \beta$ depend on the "direction" of the transition implied in the NLO phenomena and on the 
direction of the ground-state dipole moment. When $\beta$ and $\mu$ were parallel (antiparallel) and positive (negative), maximal $\mu \beta$ values were obtained.

The $\mu \beta$ values of compounds $\mathbf{1 - 1 0}$, (Table 4 ) are positive indicating excited states more polarized than the ground state $(\mu \mathrm{e}>\mu \mathrm{g})$. In addition, this implies that the ground and excited states are polarized in the same direction.

\section{$<$ Table 4>}

The $\mu \beta$ values observed for compounds 1-4 are relatively high, and similar to or higher than Disperse Red 1, as reported in literature [17]. For compounds 1, 2 and 4, an increase of the NLO response is observed after complexation (compounds 5, 6 and $\mathbf{8}$ ), however a similar response was observed for uncomplexed and complexed pyrimidine 3 and 7. The positive $\mu \beta$ values for 5-8 suggest that the pyrimidine ring serves as a primary acceptor and the amino group as a donor. The $\mathrm{W}(\mathrm{CO})_{5}$ fragment acts as an auxiliary acceptor and consequently the MLCT transition has a negligible impact on the NLO phenomena. Similar mechanism was proposed for $\mathrm{M}(\mathrm{CO})_{5}$ pyridine complexes bearing donor groups[18]. The effect of methylation is higher: compound $\mathbf{9}$ exhibits a $\mu \beta$ value more than 12 times higher than compound 2 and methylation of compound 4 results in a five-fold increase of the NLO response. The observed $\mu \beta$ for $\mathbf{9}$ is 2.8 higher than that of a corresponding iodopyridinium compound of similar length, which is in accordance with the higher pyrimidinium acceptor strength [19]. Whereas the $\mu \beta$ value clearly increases when going form phenylenevinylene derivative $\mathbf{1}$ to biphenylenevinylene compound $\mathbf{3}$, this trend is less perceptible in case of diphenylamino derivatives $\mathbf{2}$ and $\mathbf{4}$ and an important decrease of the NLO response in observed with complexed and methylated molecules. When going from $\mathrm{NMe}_{2}$ to $\mathrm{NPh}_{2}$ derivatives, a decrease of the NLO response is observed for pyrimidine compounds 1-2, 3-4. This trend is attenuated by the complexation (compounds 5-6, 7-8). 


\subsection{Computational studies}

In order to get a better insight into the electronic structure of the title compounds, DFT calculations have been performed on compounds 1-10, as well as on the hypothetical dimethylamino relatives of $\mathbf{9}$ and $\mathbf{1 0}$ which will be labeled $\mathbf{1 1}$ and $\mathbf{1 2}$ respectively, in the following discussion. Their geometries were fully optimized with and without considering solvent $\left(\mathrm{CH}_{2} \mathrm{Cl}_{2}\right)$ effect corrections (see computational details) and little differences were found between the vacuum and solvent-corrected geometries. Those of the diphenylamino series are shown in Figure 3, the dimethyl amino series being basically similar. A good agreement is found between our structural results and those obtained at a higher level of theory by Champagne and coworkers on $\mathbf{1}, \mathbf{2}$ and $\mathbf{3}$ [4d]. Relevant computed data are given in Table 5. Discarding the substituants on $\mathrm{N}(3)$ and (if any) $\mathrm{N}(2)$, compounds $\mathbf{1}, \mathbf{2}, \mathbf{5 , 6}, \mathbf{9}$ and $\mathbf{1 1}$ are almost perfectly planar, whereas compounds $3,4,7,8,10$ and 12 , which bear two sixmembered neighboring rings in their central backbone, exhibit an angle of $24-31^{\circ}$ between the two planes of these $\mathrm{C}_{6}$ rings, due to steric hindrance. Nevertheless, this moderate out-of-plane distortion still allows conjugation, as exemplified by the rather short inter-ring distance (1.46$1.47 \AA$ ). In the diphenylamino series (Figure 3), the amino phenyl groups make an angle of $42-50^{\circ}$ between them. As expected, all the computed molecules are strongly conjugated, as exemplified by planar $\left(\mathrm{sp}^{2}\right)$ bonding mode of the $\mathrm{N}(3)$ amino atom and the short $\mathrm{N}(3)$ $\mathrm{C}$ (spacer) distance (1.35-1.40 $\AA$ ). As expected, the corresponding values reported in Table 5 indicate stronger conjugative for dimethylamino rather than diphenylamino groups and for $\mathrm{D}$ $=\mathrm{NR}_{2}$ rather than $\mathrm{D}=\left(\mathrm{C}_{6} \mathrm{H}_{4}\right)-\mathrm{NR}_{2}$. The averaged bond length alternation (BLA) index of the $\mathrm{C}(1)-\mathrm{C}(7)$ string is also a good descriptor of conjugation for such compounds (BLA $=\left[\mathrm{d}_{\mathrm{C}(1) \text { - }}\right.$ (C5) $\left.\left.+\mathrm{d}_{\mathrm{C}(6)-\mathrm{C}(7)}-2 \mathrm{x} \mathrm{d}_{\mathrm{C}(5)-\mathrm{C}(6)}\right] / 2\right)$ [7]. The BLA values reported in Table 5 are all lower than 
0.12 A, i.e. indicating significant conjugative effect. The lowest BLA values (thus the strongest conjugation) correspond to the methylated cations. The presence of a $\mathrm{W}(\mathrm{CO})_{5}$ moiety on $\mathrm{N}(2)$ also increase conjugation, but to a lesser extent. As already found by Champagne and coworkers [7], the presence of two, rather than one, $\mathrm{C}_{6}$ rings on the spacer does not increase the conjugation. This is mainly due to the fact that the two neighboring rings cannot be coplanar.

The donor and acceptor fragment NPA charges are given in Table 5, together with the computed dipole moments of the neutral species (solvent effects considered). One can see that complexing the pyrimidine by $\mathrm{W}(\mathrm{CO})_{5}$ considerably increases the polarity of the molecule. Discarding the counter-anion effect, the methyl-substituted cationic species exhibit also significant acceptor-donor charge separation, especially compounds $\mathbf{1 0}$ and $\mathbf{1 2 .}$

\section{$<$ Figure 4 $>$}

The MO diagrams of compounds 1-12 are quite similar. Those of $\mathbf{1}\left(\mathrm{D}=\mathrm{NMe}_{2}\right)$ and $\mathbf{3}$ (D $=\mathrm{C}_{6} \mathrm{H}_{4} \mathrm{NMe}_{2}$ ) are shown in Figure 4. They exhibit a rather high-lying $\pi$-type HOMO which is mainly localized on the donor side of the molecule, whereas their $\pi^{*}$ LUMO has a dominant acceptor (pyrimidine) character. Adding a supplementary $\mathrm{C}_{6} \mathrm{H}_{4}$ ring in the donor fragment (compound 3) induces the existence of a supplementary level below the HOMO, which is of dominant spacer character. The presence of an acceptor $\mathrm{W}(\mathrm{CO})_{5}$ or $\mathrm{CH}_{3}{ }^{+}$ substituent on the pyrimidine does not perturb that much this general frontier MO picture, except that the polarities of the above-mentioned orbitals increase. In all the cases of the organometallic derivatives, the three occupied 4d-type orbitals associated with the $\mathrm{W}(0)$ center lie below the HOMO and are not involved in the UV-vis optical transitions, as shown by the TD-DFT calculations of which the computed absorption transitions of lower energies and significant oscillation factors are reported in Table 1. A rather good agreement with 
experiment is found for compounds 1-2 and 5-9 for which the computed wavelength correspond to a HOMO to LUMO transition, thus to a donor to acceptor charge transfer. In the case of compounds $3,4,10$ and 12 , which all have $\mathrm{a}_{6} \mathrm{H}_{4} \mathrm{NR}$ donor group, two transitions of large oscillator strength are computed, which correspond to the HOMO to LUMO and HOMO-1 to LUMO transitions, respectively. Their organometallic relatives 7 and 8 exhibit a similar transition, but mainly involving the HOMO-4, due to intercalation of the three occupied 4d-type orbitals. It is noteworthy that the wavelength corresponding to these two OS-weighted averaged transitions $(392,388,471,430$ and $477 \mathrm{~nm}$ for $\mathbf{3}, \mathbf{4} 7, \mathbf{8}$ and 10, respectively) are close to experimental $\lambda_{\max }$ values reported in Table 1 . The $\mathrm{S}_{1}$ to $\mathrm{S}_{0}$ emission wavelengths have also been computed (Table 1). Again, a rather good agreement is found with the experimental PL $\lambda_{\max }$ values. These results confirm the nature of the $\mathrm{S}_{1}$ which is a donor-to-acceptor excited state.

The optical hyperpolarizabilities have been also computed for compounds 1-12 (see computational details). The $\beta_{\text {static }}$ and $\beta_{\text {dynamic }}$ (at $1907 \mathrm{~nm}$ ) values are reported in Table 5 . Although such computed results have to be taken only at a qualitative level, one can notice that they are rather consistent with the experimental EFISH data of Table 4. The methylated derivative, and to a lesser extent their organometallic relatives are particularly suited for having interesting second-order NLO properties.

\section{$<$ Table 5>}

\section{Conclusion}

In conclusion, we have successfully synthesized and characterized push-pull 4-(arylvinyl)1-methylpyrimidinium derivatives and a series of tungsten pentacarbonyl complexes of 4(arylvinyl)pyrimidine. The optical properties including the second order nonlinear optical properties of the dyes were studied and compared to the corresponding 4- 
(arylvinyl)pyrimidines. Large and positive $\mu \beta$ values were measured for all the compounds by EFISH method. A strong increase of the $\mu \beta$ values were observed upon methylation and to lesser extend upon complexation by $\mathrm{W}(\mathrm{CO})_{5}$. According to experimental data supported by DFT theoretical calculations, the photophysical properties of these new NLO organic materials have been methodically untangled. Further investigation to combine an extension of the conjugation with the enhancement of the attracting strength of the pyrimidine ring are currently underway.

\section{Experimental section}

\subsection{General methods}

In air and moisture-sensitive reactions, all glassware was flame-dried and cooled under nitrogen. Compounds 1-4 were synthesized according to reported procedure [6]. NMR spectra were acquired at room temperature on a Bruker AC-300 or Bruker DRX500 spectrometers. Chemical shifts are given in parts per million relative to $\mathrm{CDCl}_{3}\left({ }^{1} \mathrm{H}: 7.26 \mathrm{ppm},{ }^{13} \mathrm{C}: 77.0 \mathrm{ppm}\right)$ or dmso-d6 ( $\left.{ }^{1} \mathrm{H}: 2.50 \mathrm{ppm},{ }^{13} \mathrm{C}: 39.4 \mathrm{ppm}\right)$. Acidic impurities in $\mathrm{CDCl}_{3}$ were removed by treatment with anhydrous $\mathrm{K}_{2} \mathrm{CO}_{3}$. High resolution mass analyses were performed at the “Centre Régional de Mesures Physiques de l'Ouest” (CRMPO, University of Rennes1) using a Bruker MicroTOF-Q II apparatus. IR spectra were recorded on a Perkin-Elmer spectrum1000 FTIR using KBr plates. UV/vis spectra were recorded with a UVIKON xm SECOMAM spectrometer using standard $1 \mathrm{~cm}$ quartz cells. Fluorescence spectra were recorded using Spex FluoroMax-3 Jobin-Yvon Horiba apparatus. Measurements were performed at room temperature with solutions of OD $<0.1$ to avoid re-absorption of the emitted light, and data were corrected with a blank and from the variations of the detector with the emitted wavelength. 
4.2. General procedure for the complexation of pyrimidinyl derivatives by $W(\mathrm{CO})_{5}(\mathrm{THF})$ reagent: synthesis of the pentacarbonyl complexes 5-8.

$\mathrm{W}(\mathrm{CO})_{6}(352 \mathrm{mg}, 1.0 \mathrm{mmol})$ was dissolved in degassed THF $(75 \mathrm{~mL})$. The solution was irradiated with a medium pressure mercury vapor lamp under a slight $\mathrm{N}_{2}$ positive pressure for $2.5 \mathrm{~h}$. The yellow solution of $\mathrm{W}(\mathrm{CO})_{5} \mathrm{THF}$ was transferred via cannula to a schlenk tube charged with $0.6 \mathrm{mmol}$ of pyrimidine derivative. The solution was stirred $2 \mathrm{~h}$ at $\mathrm{rt}$ under $\mathrm{N}_{2}$ atmosphere. Concentration of the solvent under vacuum afforded a red solid which was crystallized from $\mathrm{CH}_{2} \mathrm{Cl}_{2} / n$-heptane

4.3.Pentacarbonyl complex 5

Red solid; $260 \mathrm{mg}$ (79\%); mp: 158-159 ${ }^{\circ} \mathrm{C} ;{ }^{1} \mathrm{H}$ NMR (300MHz, $\left.\mathrm{CDCl}_{3}\right): \delta 3.08$ (s, 6H), 6.73 $(\mathrm{d}, 2 \mathrm{H}, J=8.7 \mathrm{~Hz}), 6.81(\mathrm{~d}, 1 \mathrm{H}, J=15.6 \mathrm{~Hz}), 7.11(\mathrm{~d}, 1 \mathrm{H}, J=6.0 \mathrm{~Hz}), 7.54(\mathrm{~d}, 2 \mathrm{H}, J=8 \mathrm{~Hz})$ $7.95(\mathrm{~d}, 1 \mathrm{H}, J=15.6 \mathrm{~Hz}), 8.71(\mathrm{~d}, 1 \mathrm{H}, J=6.0 \mathrm{~Hz}), 9.22(\mathrm{~s}, 1 \mathrm{H}) ;{ }^{13} \mathrm{C}$ NMR and JMOD (75MHz, $\left.\mathrm{CDCl}_{3}\right) \delta 202.0(\mathrm{CO}), 198.4(\mathrm{CO}), 163.4(\mathrm{C}), 162.8(\mathrm{CH}), 160.8(\mathrm{CH}), 152.0(\mathrm{C})$, $141.7(\mathrm{CH}), 130.1(\mathrm{CH}), 122.7(\mathrm{C}), 118.2(\mathrm{CH}), 118.1(\mathrm{CH}), 112.0(\mathrm{CH}), 40.1\left(\mathrm{CH}_{3}\right) ; \mathrm{IR}$ $(\mathrm{KBr}): v=2071(\mathrm{CO}), 1968(\mathrm{CO}), 1911(\mathrm{CO}) \mathrm{cm}^{-1}$; MS (ESI+) m/z: 549 [M] ${ }^{+}$. Anal. Calcd for $\mathrm{C}_{19} \mathrm{H}_{15} \mathrm{~N}_{3} \mathrm{O}_{5} \mathrm{~W}$ : C, 41.55; H, 2.75; N, 7.65. Found C, 41.77; H, 3.89; N, 7.40.

\subsection{Pentacarbonyl complex 6}

Red solid; $278 \mathrm{mg}(69 \%)$; mp: 160-161 ${ }^{\circ} \mathrm{C} ;{ }^{1} \mathrm{H}$ NMR (300MHz, $\left.\mathrm{CDCl}_{3}\right): \delta 6.89$ (d, $1 \mathrm{H}, J=$ $15.9 \mathrm{~Hz}), 7.05(\mathrm{~d}, 2 \mathrm{H}, J=8.7 \mathrm{~Hz}), 7.18-7.11(\mathrm{~m}, 7 \mathrm{H}), 7.36-7.31(\mathrm{~m}, 4 \mathrm{H}), 7.48(\mathrm{~d}, 2 \mathrm{H}, J=8.7$ $\mathrm{Hz}), 7.95(\mathrm{~d}, 1 \mathrm{H}, J=15.9 \mathrm{~Hz}), 8.79(\mathrm{~d}, 1 \mathrm{H}, J=6.0 \mathrm{~Hz}), 9.28(\mathrm{~s}, 1 \mathrm{H}) ;{ }^{13} \mathrm{C}$ NMR and JMOD (75 MHz, $\mathrm{CDCl}_{3}$ ) $\delta 201.9(\mathrm{CO}), 198.4(\mathrm{CO}), 162.93(\mathrm{C}), 162.88(\mathrm{CH}), 161.2(\mathrm{CH}), 150.2(\mathrm{C})$, $146.7(\mathrm{C}), 140.7(\mathrm{CH}), 129.6(\mathrm{CH}), 129.5(\mathrm{CH}), 127.7(\mathrm{C}), 125.6(\mathrm{CH}), 124.3(\mathrm{CH}), 121.4$ $(\mathrm{CH}), 120.7(\mathrm{CH}), 118.7(\mathrm{CH})$; IR (KBr): $v=2071(\mathrm{CO}), 1967(\mathrm{CO}), 1900(\mathrm{CO}) \mathrm{cm}^{-1}$; MS (ESI-) m/z: $708[\mathrm{M}+\mathrm{Cl}]^{-}, 1381[2 \mathrm{M}+\mathrm{Cl}]^{-}$. Anal. Calcd for $\mathrm{C}_{24} \mathrm{H}_{19} \mathrm{~N}_{3} \mathrm{O}_{5} \mathrm{~W}: \mathrm{C}, 51.73 ; \mathrm{H}, 2.84$; N, 6.24. Found C, 51.87; H, 3.09; N, 5.84. 


\subsection{Pentacarbonyl complex 7}

Red solid; $273 \mathrm{mg}(73 \%) ; \mathrm{mp} 212^{\circ} \mathrm{C}$ (dec.); ${ }^{1} \mathrm{H}$ NMR (300MHz, $\left.\mathrm{CDCl}_{3}\right): \delta 3.04$ (s, 6H), 6.83 $(\mathrm{d}, 2 \mathrm{H}, J=8.7 \mathrm{~Hz}), 7.05(\mathrm{~d}, 1 \mathrm{H}, J=15.6 \mathrm{~Hz}), 7.22(\mathrm{~d}, 1 \mathrm{H}, J=6.0 \mathrm{~Hz}), 7.59(\mathrm{~d}, 2 \mathrm{H}, J=8 \mathrm{~Hz})$, $7.66(\mathrm{~s}, 4 \mathrm{H}), 8.05(\mathrm{~d}, 1 \mathrm{H}, J=15.6 \mathrm{~Hz}), 8.84(\mathrm{~d}, 1 \mathrm{H}, J=6.0 \mathrm{~Hz}), 9.33(\mathrm{~s}, 1 \mathrm{H}) ;{ }^{13} \mathrm{C} \mathrm{NMR}$ and

JMOD (75 MHz, $\left.\mathrm{CDCl}_{3}\right) \delta 201.9(\mathrm{CO}), 198.4(\mathrm{CO}), 162.9(\mathrm{CH}), 162.8(\mathrm{C}), 161.5(\mathrm{CH})$, $150.4(\mathrm{C}), 143.4(\mathrm{C}), 140.9(\mathrm{CH}), 132.3(\mathrm{C}), 128.8(\mathrm{CH}), 127.7(\mathrm{CH}), 127.5(\mathrm{C}), 126.5(\mathrm{CH})$, $122.5(\mathrm{CH}), 119.0(\mathrm{CH}), 112.7(\mathrm{CH}), 40.4\left(\mathrm{CH}_{3}\right)$; IR (KBr): $v$ = $2071(\mathrm{CO}), 1967(\mathrm{CO}), 1902$ (CO) $\mathrm{cm}^{-1}$; MS (ESI+) m/z: $626[\mathrm{M}+\mathrm{H}]^{+}$. Anal. Calcd for $\mathrm{C}_{25} \mathrm{H}_{19} \mathrm{~N}_{3} \mathrm{O}_{5} \mathrm{~W}: \mathrm{C}, 48.02 ; \mathrm{H}, 3.06$; N, 6.72. Found C, 47.87; H, 3.18; N, 6.47.

\subsection{Pentacarbonyl complex $\boldsymbol{8}$}

Red solid; $355 \mathrm{mg}$ (79\%); mp $124^{\circ} \mathrm{C}$ (dec.); ${ }^{1} \mathrm{H}$ NMR (300MHz, $\left.\mathrm{CDCl}_{3}\right)$ : $\delta$ 7.11-7.05 (m, $3 \mathrm{H}), 7.18-7.15(\mathrm{~m}, 6 \mathrm{H}), 7.24\left(\mathrm{dd}, 1 \mathrm{H}, J_{l}=6.0 \mathrm{~Hz}, J_{l}=0.9 \mathrm{~Hz}\right), 7.33-7.29(\mathrm{~m}, 4 \mathrm{H}), 7.54(\mathrm{~d}$, $2 \mathrm{H}, J=8.7 \mathrm{~Hz}), 7.66(\mathrm{~d}, 2 \mathrm{H}, J=8.7 \mathrm{~Hz}), 7.71(\mathrm{~d}, 2 \mathrm{H}, J=8.7 \mathrm{~Hz}), 8.06(\mathrm{~d}, 1 \mathrm{H}, J=15.9 \mathrm{~Hz})$ $8.87\left(\mathrm{dd}, 1 \mathrm{H}, J_{l}=6.0 \mathrm{~Hz}, J_{1}=0.9 \mathrm{~Hz}\right), 9.35(\mathrm{~s}, 1 \mathrm{H}) ;{ }^{13} \mathrm{C} \mathrm{NMR}$ and JMOD $\left(75 \mathrm{MHz}, \mathrm{CDCl}_{3}\right)$

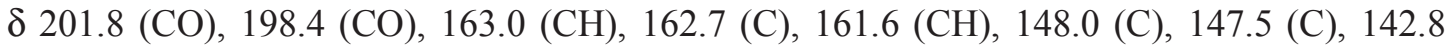
(C), $140.6(\mathrm{CH}), 133.3(\mathrm{C}), 133.2(\mathrm{C}), 129.4(\mathrm{CH}), 128.8(\mathrm{CH}), 127.6(\mathrm{CH}), 127.0(\mathrm{CH})$, 124.6 (CH), $123.4(\mathrm{CH}), 123.3(\mathrm{CH}), 123.0(\mathrm{CH}), 119.0(\mathrm{CH})$; IR $(\mathrm{KBr}): v=2071(\mathrm{CO}), 1977$ (CO), $1916(\mathrm{CO}) \mathrm{cm}^{-1}$; MS (ESI+) m/z: 693 [M-2CO $]^{+}, 749[\mathrm{M}]^{+}$.Anal. Calcd for $\mathrm{C}_{35} \mathrm{H}_{23} \mathrm{~N}_{3} \mathrm{O}_{5} \mathrm{~W}: \mathrm{C}, 56.09 ; \mathrm{H}, 3.09 ; \mathrm{N}, 5.61$. Found C, 56.27; H, 3.24; N, 5.45..

4.7. General procedure for the methylation of pyrimidinyl derivatives.

A mixture of pyrimidine derivative $(1.0 \mathrm{mmol})$ and methyl iodide $(2 \mathrm{~mL})$ was stirred for $3 \mathrm{~h}$. The methyl iodide was evaporated under vacuum. The crude product was used without further purification.

4.8.(E)4-[2-(4-Diphenylamino-phenyl)-vinyl]-1-methyl-pyrimidin-1-ium iodide (9) 
Green solid; $304 \mathrm{mg}(62 \%) ;{ }^{1} \mathrm{H}$ NMR $\left(500 \mathrm{MHz}, \mathrm{dmso}_{6}\right): \delta 4.10$ (s, 3H), 6.89 (d, 2H, $J=$ $9.0 \mathrm{~Hz}), 7.21-7.14(\mathrm{~m}, 6 \mathrm{H}), 7.33(\mathrm{~d}, 1 \mathrm{H}, J=15.5 \mathrm{~Hz}), 7.41-7.38(\mathrm{~m}, 4 \mathrm{H}), 7.71(\mathrm{~d}, 2 \mathrm{H}, J=9.0$ Hz), 8.04 (d, 1H, $J=6.5 \mathrm{~Hz}), 8.22$ (d, 1H, $J=15.5 \mathrm{~Hz}), 8.95$ (d, 1H, $J=6.5 \mathrm{~Hz}), 9.40$ (s, 1H);

${ }^{13} \mathrm{C}$ NMR and JMOD (125 MHz, dmso-d 6 ) $\delta 167.3(\mathrm{C}), 150.7(\mathrm{CH}), 150.6(\mathrm{C}), 145.8(\mathrm{C})$, $145.2(\mathrm{CH}), 131.0(\mathrm{CH}), 129.9(\mathrm{CH}), 126.7(\mathrm{C}), 125.9(\mathrm{CH}), 125.1(\mathrm{CH}), 120.3(\mathrm{CH}), 119.6$ $(\mathrm{CH}), 118.4(\mathrm{CH})$; HRMS (ESI/ASAP) m/z calculated for $\mathrm{C}_{25} \mathrm{H}_{22} \mathrm{~N}_{3}[\mathrm{M}]^{+}$364.1814, found 364.1813.

4.9.(E)4-[2-(4'-Diphenylamino-biphenyl-4-yl)-vinyl]-1-methyl-pyrimidin-1-ium iodide (10)

Green solid; $527 \mathrm{mg}$ (93\%); mp: $175-176{ }^{\circ} \mathrm{C}{ }^{1} \mathrm{H}$ NMR (500MHz, dmso-d 6 ): $\delta 4.14$ (s, 3H), $7.02(\mathrm{~d}, 2 \mathrm{H}, J=9.0 \mathrm{~Hz}), 7.10-7.06(\mathrm{~m}, 6 \mathrm{H}), 7.35-7.32(\mathrm{~m}, 4 \mathrm{H}), 7.61(\mathrm{~d}, 1 \mathrm{H}, J=15.5 \mathrm{~Hz})$, $7.69(\mathrm{~d}, 2 \mathrm{H}, J=9.0 \mathrm{~Hz}), 7.79(\mathrm{~d}, 2 \mathrm{H}, J=9.0 \mathrm{~Hz}), 7.91$ (d, 2H, $J=9.0 \mathrm{~Hz}), 8.15$ (d, 1H, $J=$ $6.5 \mathrm{~Hz}), 8.32(\mathrm{~d}, 1 \mathrm{H}, J=15.5 \mathrm{~Hz}), 9.07(\mathrm{~d}, 1 \mathrm{H}, J=6.5 \mathrm{~Hz}), 9.50(\mathrm{~s}, 1 \mathrm{H}) ;{ }^{13} \mathrm{C}$ NMR and JMOD (125 MHz, dmso-d 6 ) $\delta 167.2(\mathrm{C}), 151.6(\mathrm{CH}), 147.6(\mathrm{C}), 146.8(\mathrm{C}), 144.6(\mathrm{CH}), 142.3$ (C), $132.9(\mathrm{C}), 132.2(\mathrm{C}), 129.8(\mathrm{CH}), 129.7(\mathrm{CH}), 127.8(\mathrm{CH}), 126.6(\mathrm{CH}), 124.5(\mathrm{CH})$, $123.6(\mathrm{CH}), 123.2(\mathrm{CH}), 122.6(\mathrm{CH}), 119.3(\mathrm{CH})$; HRMS (ESI/ASAP) m/z calculated for $\mathrm{C}_{31} \mathrm{H}_{26} \mathrm{~N}_{3}[\mathrm{M}]^{+}$440.2127, found 440.2125.

\section{Computational details}

Geometry optimizations were carried out using the Gaussian 09 package, ${ }^{20}$ employing the PBE0 functional, ${ }^{21}$ and using the standard double- $\xi$ LANL2DZ basis set ${ }^{22}$ augmented with Ahlrichs polarization functions. ${ }^{23}$ All stationary points were fully characterized via analytical frequency calculations as true minima (no imaginary values). Solvent $\left(\mathrm{CH}_{2} \mathrm{Cl}_{2}\right)$ effects have been taken into account using the PCM model. ${ }^{24}$ The geometries obtained from DFT calculations were used to perform natural atomic orbital analysis with the NBO 5.0 program. ${ }^{25}$ The composition of the molecular orbitals was calculated using the AOMix program. ${ }^{26}$ The 
ionization energies and electron affinities discussed above have been calculated considering the energies of the optimized neutral and ionic structures (solvent corrections performed). The UV visible transitions were calculated by means of TDDFT calculations ${ }^{27}$ at the same level of theory. Only singlet-singlet transitions have been taken into account. Only the transitions with non-negligible oscillator strengths are discussed in the paper. Static and frequency-dependent electronic (hyper)polarizability tensor components $\beta_{i j j}(i, j=x, y, z)$ were obtained through the Coupled-Perturbed Hartree-Fock procedure ${ }^{28}$ using the more appropriate wB97XD functional ${ }^{29}$ with the same basis set as above. Dynamic (hyper)polarizabilities are computed assuming a laser wavelength of $1907 \mathrm{~nm}(\hbar \omega=0.023896$ a.u. $)$ for the SHG $[\beta(-2 \omega ; \omega, \omega)]$ NLO processes.

\section{Acknowledgement.}

JYS thanks the Institut Universitaire de France for support.

\section{Supplementary informations}

Supplementary data related to this article can be found at http://dx.doi.org 
Scheme 1: Synthesis of compounds 5-8

Scheme 2: Synthesis of compounds 9-12

Table 1. UV/Vis and photoluminescence (PL) data

Table 2. Absorption maxima of 9 in various solvents

Table 3. Absorption maxima of $\mathrm{CH}_{2} \mathrm{Cl}_{2}$ solution of 9 at various concentrations.

Table 4. $\mu \beta$ values for compounds 1-10

Table 5. Selected computed data (solvent corrections considered).

Figure 1: Normalized UV/vis of compounds 2,6 and 9 in $\mathrm{CH}_{2} \mathrm{Cl}_{2}$.

Figure 2: Normalized UV/vis of compounds 9 in various solvents.

Figure 3. Optimized molecular structures of the computed diphenylamino derivatives.

Figure 4. MO diagrams on 1 and 3. The numbers correspond to the following fragment localisations (\%): pyrimidine (nitogen atoms) $/ \mathrm{C}(5)=\mathrm{C}(6) / \mathrm{C}_{6} \operatorname{ring}(\mathrm{s}) / \operatorname{amine} \operatorname{group}(\mathrm{N})$.

[1] a) Chemla DS, Zyss J, editors. Nonlinear optical properties of organic molecules and crystals, vols. 1 and 2. Orlando, USA: Academic Press; 1987. b) Papadopoulos MG, Sadlej AJ, Leszczynski J, editors. Non-linear optical properties of matter: from molecules to condensed phases. Dordrecht, The Netherlands: Springer; 2006. 
[2] a) Achelle S, Plé N, Pyrimidine ring as building block for the synthesis of functionalized $\pi$-conjugated materials. Curr Org Synth 2012;9:163-87. B) Achelle S, Baudequin C, Recent advances in pyrimidine derivatives as luminescent, photovoltaic and non-linear optical materials. Targets Heterocycl Syst 2013;17:1-34.

[3] see for example a) Liu B, Hu XL, Liu J, Zhao YD, Huang ZL. Synthesis and photophysical properties of novel pyrimidine-based two-photon absorption chromophores. Tetrahedron Lett 2007;48:5958-62. b) Li L, Ge J, Wu H, Xu QH, Yao S Q. Organelle-specific detection of phosphatase activities with two-photon fluorogenic probes in cells and tissues. J Am Chem Soc 2012;134:12157-67. c) Achelle S, Malval JP, Aloïse S, Barsella A, Spangenberg A, Mager L, Akdas-Killig H, Fillaut JL, Caro B, Robin-le Guen F. Synthesis, photophysics and nonlinear optical properties of stilbenoid pyrimidine-based dyes bearing methylenepyran donor groups. ChemPhysChem 2013;14:2725-36. d) Savel P, Akdas-Kilig H, Malval JP, Spangenberg A, Roisnel T, Fillaut JL, Metal-induced dimensionality tuning in a series of bipyrimidine-based ligands: a tool to enhance two-photon absorption. J Mater Chem C 2014;2:295-305

[4] a) Akdas-Kilig H, Roisnel T, Ledoux I, Le Bozec H, A new class of bipyrimidine-based octupolar chromophores: synthesis, fluorescent and quadratic non-linear optical properties. New J Chem 2009;33:1470-3. b) Achelle S, Kahlal S, Saillard JY, Cabon N, Caro B, Robin-le Guen F Tetrahedron 2014;70:2804-15.

[5] a) Achelle S, Ramondenc Y, Marsais F, Plé N. Star- and banana-shaped oligomers with a pyrimidine core: synthesis and light-emitting properties. Eur J Org Chem 2009;3129-40 b) Achelle S, Ramondenc Y, Dupas G, Plé N. Bis- and tri(arylethynyl)pyrimidine oligomers : synthesis and light-emitting properties. Tetrahedron 2008;64:2783-91 c) Achelle S, Nouira I, Pfaffinger B, Ramondenc Y, Plé N, Rodríguez-López J V-shaped 4,6bis(arylvinyl)pyrimidine ologomers: synthesis and optical properties J Org Chem 
2009;74:3711-7. d) Achelle S, Saettel N, Baldeck P, Teulade-Fichou MP, Maillard P. Bisporphyrin connected by pyrimidine: synthesis and photophysical properties. J Porphyrins Phthalocyanines 2010;14:877-84. e) Hadad C, Achelle S, García-Marticnez JC, RodríguezLópez J. 4-arylvinyl-2,6-di(pyridine-2-yl)pyrimidines: synthesis and optical properties. J Org Chem 2011;76:3837-45. f) Achelle S, Robin-le Guen F. 2-arylvinylpyrimidines versus 4arylvinylpyrimidines: synthesis and comparison of the optical properties. Tetrahedron Lett 2013;54:4491-6.

[6] Achelle S, Barsella, A, Baudequin C, Caro B, Robin-le Guen F, Synthesis and photophysical investigation of a series of push-pull arylvinyldiazine chromophores. J Org Chem 2012;77:4087-96.

[7] Castet F, Pic A, Champagne B, Linear and nonlinear optical properties of arylvinyldiazine dyes: a theoretical investigation. Dyes Pigm 2014;110:250-60.

[8] Clays K, Coe BJ. Design strategies versus limiting theory for engineering large secondorder nonlinear optical polarizabilities in charged organic molecules. Chem Mater $2003 ; 15: 642-8$.

[9] Cariati E, Dragonetti C, Lucenti E, Nisic F, Righetto S, Roberto D, Tordin E. An acidotriggered reversible luminescent and nonlinear optical switch based on a substituted styrylpyridine: EFISH measurements as an unusual method to reveal a protonationdeprotonation NLO contrast. Chem Commun 2014;50:1608-10.

[10] a) Ramírez MA, Cuadro MA, Alvarez-Builla J, Castaño O, Andrés JL, Mendicuti F, Clays K, Asselberghs I, Vaquero JJ. Donor- $\pi$-bridge)azinium as D- $\pi$ - $\mathrm{A}^{+}$one-dimentional and D- $\pi$-A $\mathrm{A}^{+}-\pi$-D multidimentional V-shaped chromophores. Org Biomol Chem 2012;10:165969. b) Ramirez MA, Custodio R, Cuadro AM, Alvarez-Builla J, Clays K, Asselberths I, Mendicuti F, Castaño O, Andrés JL. Synthesis of charged bis-heteroaryl donor-acceptor (D- 
$\mathrm{A}^{+}$) NLO-phores coupling ( $\pi$-deficient- $\pi$-excessive) heteroaromatic rings. Org Biomol Chem 2013;11:7145-54. c) Ramirez MA, Cañeque T, Cuadro AM, Mendicuti F, Clays K, Asselbergh I, Vaquero JJ. Novel linear and V-shaped D- $\pi-A^{+}-\pi$-D chromophores by Sonogashira reaction Arkivoc 2011;ii:1470-55. d) Quist F, Vande Velde CML, Didier D, Teshome A, Asselberghs I, Clays K, Sergeyev S. Push-pull chromophores comprising benzothiazolium acceptor and thiophene auxiliary donor moieties: synthesis, structure, linear and quadratic non-linear optical properties. Dyes Pigm 2009;81:203-10.

[11] a) Pizzotti M, Ugo R, Roberto D, Bruni S, Organometallic Counterparts of Push-Pull Aromatic Chromophores for Nonlinear Optics: Push-Pull Heteronuclear Bimetallic Complexes with Pyrazine and trans-1 , 2-Bis(4-pyridyl)ethylene as Linkers, Organometallics 2002;21:5830-40. b) Mata J, Uriel S, Peris E, Llusar R, Houbrechts S, Perssons A. Synthesis and characterization of new ferrocenyl heterobimetallic compounds with high NLO responses. J Organomet Chem 1998;562:197-202. c) Lamère JF, Sasaki I, Lacroix PG, Nakatani K. The effect of the conformation on the quadratic nonlinear optical response of metal carbonyl based chromophores with one-dimentional charge transfer capabilities: a computational investigation. New J Chem 2006;30:921-8.

[12] a) Gauthier S, Vologdin N, Achelle S, Barsella A, Caro B, Robin-le Guen F. Methylenepyran-based dipolar and quadrupolar dyes: synthesis, electrochemical and photophysical properties. Tetrahedron 2013;69:8392-9 b) Klikar M, Bureš F, Pytela O, Mikysek T, Padělková Z, Barsella A, Dorkenoo K, Achelle S. N,N'dibutylbarbituric acid as an acceptor moiety in push-pull chromophores. New J Chem 2013;37:4230-40.

[13] Ba F, Robin-le Guen F, Cabon N, le poul P, Gohlen S, le Poul N, Caro B. Ferrocenyl and pyridyl methylenepyrans as potential precursors of organometallic electron-rich extended bipyrans: synthesis, characterization and crystal structure. J Organomet Chem 2010;698:23543. 
[14] a) Gao Y, Shreeve JM, Quaternization of pyrazine, pyridazine and pyrimidine with alkyl and polyfluoroalkyl halides: formation of low melting salts. Synthesis 2004;7:1072-82. b) Duffin GF, The quaternarization of heterocyclic compounds vol 3; 1964:p. 1-56. c) Aranda AI, Achelle S, Hammerer F, Mahuteau-Betzer F, Teulade-Fichou MP. Vinyl-diazine triphenylamines and their N-methylated derivatives: synthesis, photophysical properties and application for staining DNA. Dyes Pigm 2012;95:400-7.

[15] Ooyama Y, Oda Y, Mizumo T, Ohshita J, Specific solvatochromism of D- $\pi$-A type pyrimidinium dyes bearing va\&rious counter anions in halogenated solvents. Tetrahedron 2013;69:1755-60.

[16] a) Singer KD, Garito AF, Measurements of molecular $2^{\text {nd }}$ order optical susceptibilities using DC induced $2^{\text {nd }}$ harmonic-generation. J Chem Phys 1981;75:3572-80. b) Levine BF, Bethea CG, Molecular hyperpolarizabilities determined from conjugated and nonconjugated organic liquids. Appl Phys Lett 1974;24;445-7. c) Ledoux I, Zyss J, Influence of the molecular enrironment in solution measurements of the $2^{\text {nd }}$ order optical susceptibility for urea and derivatives. Chem Phys 1982;73:203-13. d) Thami T, Bassoul P, Petit MA, Simon J, Fort A, Barzoukas M, Villaeys A, Highly polarizable metallic complexes for nonlinear optics - cobaltous complexes of unsymmetrical hydrazone imine glyoxal derivatives. J Am Chem Soc 1992;114:915-21.

[17] Cheng LT, Tam W, Stevenson SH, Meredith GR, Rikken G, Marder SR Experimental investigations of organic molecular nonlinear optical polarizabilities.1. methods and results on benzene and stilbene derivatives. .J Phys Chem 1991;95:10631-43.

[18] Kanis DR, Lacroix PG, Ratner MA, Marks TJ. Electronic structure and quadratic hyperpolarizabilities in organotransition-metal chromophores having weakly coupled $\pi$ networks. Unusual mechanisms for second-order response. J Am Chem Soc 1994;116:10089102. 
[19] Alain V, Blanchard-Desce M, Leroux-Rak I, Zyss J. Amphiphilic polyenic push-pull chromophores for nonlinear optical application. Chem Commun 2000;353-4.

[20] Frisch MJ, Trucks GW, Schlegel HB, Scuseria GE, Robb MA, Cheeseman JR, JAJr Montgomery JAJr, Vreven T, Kudin KN, Burant JC, Millam JM, Iyengar SS, Tomasi J, Barone V, Mennucci B, Cossi M, Scalmani G, Rega N, Petersson GA, Nakatsuji H, Hada M, Ehara M, Toyota K, Fukuda R, Hasegawa J, Ishida M, Nakajima T, Honda Y, Kitao O, Nakai H, Klene M, Li X, Knox JE, Hratchian HP, Cross JB, Adamo C, Jaramillo J, Gomperts R, Stratmann RE, Yazyev O, Austin AJ, Cammi R, Pomelli C, Ochterski JW, Ayala PY, Morokuma K, Voth GA, Salvador P, Dannenberg JJ, Zakrzewski VG, Dapprich S, Daniels AD, Strain MC, Farkas O, Malick DK, Rabuck AD, Raghavachari K, Foresman JB, Ortiz JV, Cui Q, Baboul AG, Clifford S, Cioslowski J, Stefanov BB, Liu G, Liashenko A, Piskorz P, Komaromi I, Martin RL, Fox DJ, Keith T, Al-Laham MA, Peng CY, Nanayakkara A, Challacombe M, Gill PMW, Johnson B, Chen W, Wong MW, Gonzalez C, Pople JA, Gaussian 03, revision B. 04; Gaussian, Inc.: Pittsburgh, PA, 2003.

[21] a) Perdew JP, Ernzerhof M, Burke K Rationale for mixing exact exchange with density functional approximations J Chem Phys 1996;105:9982-5. b) Perdew, JP, Burke K, Ernzerhof M Generelized gradient approximation made simple. Phys Rev Lett 1996;77:3865-8. c) Perdew JP, Burke K, Ernzerhof M Generalized gradient approximation made simple Phys Rev Lett 1997;78:1396.

[22] a) Dunning JrTH, Hay PJ In Methods of Electronic Structure Theory; Schaeffer, H. F., Ed.; Plenum Press: New York, 1977. b) Hay PJ, Wadt WR Abinitio effective core potentials for molecular calculations - potentials for the transition-metal atoms Sc to Hg. J Chem Phys 1985;82:270-83. c) Hay PJ, Wadt WR Abinitio effective core potentials for molecular calculations - potentials for the transition-metal atoms Na to Bi. J Chem Phys 1985;82:28498. d) Hay PJ, Wadt WR Abinitio effective core potentials for molecular calculations - 
potentials for the transition-metal atoms $\mathrm{K}$ to Au including the outermost core orbitals. $\mathrm{J}$ Chem Phys 1985;82:299-310.

[23] Schafer A, Horn H, Ahlrichs R. Fully optimized contracted gaussian-basis sets for atoms Li to Kr. J Chem Phys 1992;97:2571-7.

[24] a) Cossi M, Scalmani G, Rega N, Barone V New developments in the polarizable continuum model for quantum mechanical and classical calculations on molecules in solution J Chem Phys 2002;117:43-54. b) Barone V, Cossi M, Tomasi J A new definition of cavities for the computation of solvation free energies by the polarizable continuum model J Chem Phys 1997;107:3210-21.

[25] Glendening ED, Badenhoop JK, Reed AE, Carpenter JE, Bohmann JA, Morales CM, Weinhold F Theoretical Chemistry Institute, University of Wisconsin, Madison, WI, 2001, http://www.chem.wisc.edu/ nbo5

[26] Gorelsky SI AOMix program, http://www.sg-chem.net/

[27] Burke K, Gross, EKU In A guided tour of Time-Dependent Density Functional Theory, in Density Functionals: Theory and Applications, (Lecture Notes in physics), Vol. 500; D. Joubert Ed.; Springer, 1998.

[28] a) Sekino H, Bartlett RJ Frequency-dependent nonlinear optical-properties of molecules. J Chem Phys 1986;85:976-89. b) Rice JE, Handy NC The calculation of frequency-dependent hyperpolarizabilities including electron correlation-effects. Int J Quantum Chem 1992;43:91118.

[29] Chai JD, Head-Gordon M. Long-range corrected hybrid density functionals with damped atom-atom dispersion corrections Phys Chem Chem Phys 2008;10:6615-20. 


\begin{tabular}{|c|c|c|c|c|c|c|}
\hline Compd $^{a}$ & $\begin{array}{c}\mathrm{UV} / \mathrm{vis} \lambda_{\max }, \mathrm{nm} \\
\left(\varepsilon, \mathrm{mM}^{-1} \cdot \mathrm{cm}^{-1}\right)\end{array}$ & $\begin{array}{c}\text { Computed } \\
\text { absorption } \\
\text { transition }(\mathrm{nm}) \\
\text { and } \mathrm{OS}^{\mathrm{e}}\end{array}$ & $\begin{array}{l}\text { Computed } \\
\text { emission } \\
\text { transition } \\
(\mathrm{nm})^{\mathrm{e}}\end{array}$ & $\begin{array}{c}\mathrm{PL} \\
\lambda_{\max }, \mathrm{nm}\end{array}$ & $\Phi_{\mathrm{F}}^{\mathrm{b}}$ & $\begin{array}{c}\text { Stokes shift } \\
\mathrm{cm}^{-1}\end{array}$ \\
\hline $1^{\mathrm{c}}$ & $393(28.6)$ & $411(1.20)$ & 473 & 488 & 0.15 & 4953 \\
\hline $2^{c}$ & $400(32.0)$ & $438(1.10)$ & 520 & 526 & 0.45 & 5989 \\
\hline $3^{\mathrm{c}}$ & $386(32.4)$ & $\begin{array}{l}451(1.09) \\
322(0.66)\end{array}$ & 542 & 570 & 0.66 & 8362 \\
\hline $4^{c}$ & $384(35.4)$ & $\begin{array}{l}452(0.99) \\
339(0.97)\end{array}$ & 548 & 564 & 0.52 & 8280 \\
\hline 5 & $462(31.3)$ & $459(1.51)$ & & $-{ }^{d}$ & $-{ }^{d}$ & $-{ }^{d}$ \\
\hline 6 & $462(33.4)$ & $486(1.44)$ & & $-{ }^{d}$ & $-{ }^{d}$ & $-{ }^{d}$ \\
\hline 7 & $443(27.2)$ & $\begin{array}{l}507(1.31) \\
335(0.23)\end{array}$ & & $-{ }^{d}$ & $-{ }^{d}$ & $-{ }^{d}$ \\
\hline 8 & 435 (28.6) & $\begin{array}{l}506(1.14) \\
352(0.77)\end{array}$ & & $-{ }^{d}$ & $-{ }^{d}$ & $-{ }^{d}$ \\
\hline 9 & $564(40.3)$ & $534(1.35)$ & & $-{ }^{d}$ & $-{ }^{d}$ & $-{ }^{d}$ \\
\hline 10 & $520(34.6)$ & $\begin{array}{l}633(0.83) \\
402(1.09)\end{array}$ & & $-{ }^{d}$ & $-{ }^{d}$ & $-{ }^{d}$ \\
\hline $11^{\mathrm{f}}$ & & $482(1.47)$ & & & & \\
\hline $12^{\mathrm{f}}$ & & $\begin{array}{l}617(1.12) \\
378(0.82)\end{array}$ & & & & \\
\hline
\end{tabular}

${ }^{a}$ All spectra were recorded in $\mathrm{CH}_{2} \mathrm{Cl}_{2}$ solutions at room temperature at $c=1.0 \times 10^{-5} \mathrm{M}$ to 3.0 $\times 10^{-5} \mathrm{M}$ for absorption and $c=1.0 \times 10^{-6} \mathrm{M}$ to $3.0 \times 10^{-6} \mathrm{M}$ for emission. ${ }^{b}$ Fluorescence quantum yield $( \pm 10 \%)$ determined relative to quinine sulfate in $1 \mathrm{M} \mathrm{H}_{2} \mathrm{SO}_{4}\left(\Phi_{\mathrm{F}}=0.54\right){ }^{\mathrm{c}}$ results from ref. [6]. ${ }^{\mathrm{d}}$ : no fluorescence detected. ${ }^{\mathrm{e}}$ From TD-DFT calculations. OS = oscillation strength factor. ${ }^{\mathrm{f}}$ hypothetical compound. 


\begin{tabular}{ccccccccc}
\hline & $\begin{array}{c}n- \\
\text { heptane }\end{array}$ & Toluene & THF & $\mathbf{C H C l}_{\mathbf{3}}$ & $\mathbf{C H}_{\mathbf{2}} \mathbf{C l}_{\mathbf{2}}$ & $\mathbf{M e C N}$ & DMSO & MeOH \\
\hline $\begin{array}{c}\text { UV/vis } \lambda_{\max }, \\
\mathrm{nm}\end{array}$ & 503 & 521 & 507 & 545 & 550 & 502 & 492 & 506 \\
\hline
\end{tabular}




\begin{tabular}{cccccc}
\hline Concentration $(\mathrm{M})$ & $7.3410^{-6}$ & $1.4710^{-5}$ & $2.2010^{-5}$ & $2.5410^{-5}$ & $7.3510^{-5}$ \\
\hline $\mathrm{UV} / \mathrm{vis} \lambda_{\max }, \mathrm{nm}$ & 564 & 556 & 554 & 552 & 546 \\
$\left(\varepsilon, \mathrm{mM}^{-1} \cdot \mathrm{cm}^{-1}\right)$ & $(40.3)$ & $(39.3)$ & $(40.7)$ & $(40.4)$ & $(37.5)$ \\
\hline
\end{tabular}




\begin{tabular}{|c|c|c|c|c|c|c|c|c|c|c|}
\hline & 1 & 2 & 3 & 4 & 5 & 6 & 7 & 8 & 9 & 10 \\
\hline$\mu \beta\left[10^{-48} \text { esu }\right]^{a}$ & 330 & 190 & 470 & 200 & 770 & 700 & 490 & 460 & 2350 & 1080 \\
\hline
\end{tabular}




\begin{tabular}{|c|c|c|c|c|c|c|c|c|c|c|c|c|}
\hline & 1 & 2 & 3 & 4 & 5 & 6 & 7 & 8 & 9 & 10 & 11 & 12 \\
\hline $\begin{array}{l}\text { HOMO/LUMO } \\
\text { gap (eV) }\end{array}$ & 3.52 & 3.39 & 3.21 & 3.21 & 3.20 & 3.09 & 2.89 & 2.89 & 2.72 & 2.31 & 2.91 & 2.34 \\
\hline \multicolumn{13}{|l|}{ Distances $(\AA)$ : } \\
\hline $\mathrm{C}(1)-\mathrm{C}(2)$ & 1.400 & 1.398 & 1.397 & 1.397 & 1.403 & 1.400 & 1.399 & 1.398 & 1.413 & 1.409 & 1.416 & 1.411 \\
\hline $\mathrm{C}(2)-\mathrm{N}(1)$ & 1.347 & 1.345 & 1.344 & 1.344 & 1.350 & 1.348 & 1.347 & 1.346 & 1.356 & 1.352 & 1.360 & 1.354 \\
\hline $\mathrm{N}(1)-\mathrm{C}(4)$ & 1.321 & 1.321 & 1.321 & 1.321 & 1.310 & 1.310 & 1.311 & 1.311 & 1.297 & 1.299 & 1.296 & 1.298 \\
\hline$C(4)-N(2)$ & 1.331 & 1.331 & 1.331 & 1.331 & 1.342 & 1.342 & 1.342 & 1.342 & 1.347 & 1.346 & 1.347 & 1.346 \\
\hline $\mathrm{N}(2)-\mathrm{C}(3)$ & 1.336 & 1.335 & 1.334 & 1.334 & 1.346 & 1.345 & 1.344 & 1.343 & 1.353 & 1.351 & 1.355 & 1.352 \\
\hline $\mathrm{C}(3)-\mathrm{C}(1)$ & 1.378 & 1.379 & 1.380 & 1.380 & 1.370 & 1.372 & 1.373 & 1.373 & 1.359 & 1.361 & 1.357 & 1.360 \\
\hline $\mathrm{C}(5)-\mathrm{C}(6)$ & 1.348 & 1.345 & 1.344 & 1.343 & 1.353 & 1.349 & 1.347 & 1.345 & 1.360 & 1.353 & 1.365 & 1.356 \\
\hline BLA $^{\mathrm{a}}$ & 0.097 & 0.104 & 0.108 & 0.110 & 0.084 & 0.094 & 0.099 & 0.103 & 0.067 & 0.082 & 0.055 & 0.076 \\
\hline $\begin{array}{l}\text { C(ring)-C(ring): } \\
\text { [range] } \\
\text { average }\end{array}$ & $\begin{array}{l}{[1.375-1.416]} \\
1.398\end{array}$ & $\begin{array}{l}{[1.377-1.403]} \\
1.394\end{array}$ & $\begin{array}{l}{[1.381-1.409]} \\
1.395\end{array}$ & $\begin{array}{l}{[1.379-1.402]} \\
1.393\end{array}$ & $\begin{array}{l}{[1.373-1.417]} \\
1.398\end{array}$ & $\begin{array}{l}{[1.376-1.405]} \\
1.394\end{array}$ & $\begin{array}{l}{[1.378-1.410]} \\
1.395\end{array}$ & $\begin{array}{l}{[1.379-1.403]} \\
1.394\end{array}$ & $\begin{array}{l}{[1.371-1.410]} \\
1.396\end{array}$ & $\begin{array}{l}{[1.376-1.405]} \\
1.394\end{array}$ & $\begin{array}{l}{[1.368-1.417]} \\
1.399\end{array}$ & $\begin{array}{l}{[1.37-1.412]} \\
1.396\end{array}$ \\
\hline $\mathrm{C}(\mathbf{1 0 / 1 6 ) - N ( 3 )}$ & 1.357 & 1.396 & 1.367 & 1.402 & 1.354 & 1.391 & 1.365 & 1.401 & 1.379 & 1.396 & 1.346 & 1.357 \\
\hline$N(3)-C(R)$ & 1.445 & 1.414 & 1.444 & 1.411 & 1.446 & 1.416 & 1.444 & 1.412 & 1.420 & 1.413 & 1.448 & 1.444 \\
\hline $\mathrm{W}-\mathrm{N}(2) / \mathrm{Me}-\mathrm{N}(2)$ & & & & & 2.289 & 2.291 & 2.293 & 2.291 & 1.460 & 1.461 & 1.461 & 1.460 \\
\hline \multicolumn{13}{|l|}{$\begin{array}{l}\text { NPA fragment } \\
\text { charges: }\end{array}$} \\
\hline $\mathrm{A}^{\mathrm{b}}$ & -0.14 & -0.12 & -0.11 & -0.10 & -0.41 & -0.16 & -0.15 & -0.14 & 0.70 & 0.20 & 0.41 & 0.17 \\
\hline $\mathbf{D}^{\mathrm{b}}$ & 0.07 & -0.08 & 0.05 & 0.03 & 0.08 & -0.06 & 0.07 & 0.04 & 0.00 & 0.43 & 0.13 & 0.52 \\
\hline $\mathbf{N R}_{2}$ & 0.07 & -0.08 & 0.03 & -0.11 & 0.08 & -0.06 & 0.04 & -0.11 & 0.00 & 0.59 & 0.13 & 0.68 \\
\hline $\begin{array}{l}\text { Dipole moment } \\
\text { (Debye) }\end{array}$ & 9.8 & 6.2 & 9.0 & 5.6 & 19.1 & 15.3 & 17.9 & 14.0 & & & & \\
\hline$\beta_{\text {static }}\left(10^{-30} \mathrm{esu}\right)$ & 103 & 96 & 112 & 90 & 151 & 140 & 157 & 119 & 307 & 285 & 264 & 386 \\
\hline $\begin{array}{l}\beta_{\text {dynamic }}\left(10^{-30}\right. \\
\left.\text { esu }^{c}\right)^{c}\end{array}$ & 133 & 124 & 144 & 115 & 204 & 189 & 208 & 155 & 458 & 403 & 395 & 574 \\
\hline
\end{tabular}

${ }^{a}$ Bond length alternation index : $\mathrm{BLA}=\left[\mathrm{d}_{\mathrm{C}(1)-\mathrm{C}(5)}+\mathrm{d}_{\mathrm{C}(6)-\mathrm{C}(7)}-2 \mathrm{x} \mathrm{d}_{\mathrm{C}(5)-\mathrm{C}(6)}\right] / 2$ (see Figure 3 ).

${ }^{\mathrm{b}} \mathrm{A}=$ acceptor (pyrimidine or substituted pyrimidine); $\mathrm{D}=$ donor, as defined in Schemes 1 and 2.

${ }^{\mathrm{c}}$ Assuming a $1907 \mathrm{~nm}$ laser wavelength. 


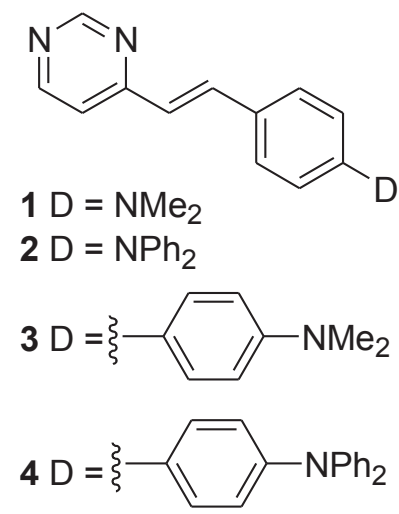

$\underset{\mathrm{THF}, \mathrm{rt}, 2 \mathrm{~h}}{\stackrel{\mathrm{W}(\mathrm{CO})_{5} \cdot \mathrm{THF}}{\longrightarrow}}$

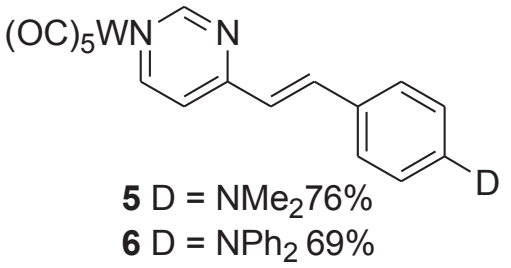

$7 \mathrm{D}=\left\{-\mathrm{NMe}_{2} \quad 73 \%\right.$

$8 \mathrm{D}=\left\{-\mathrm{NPh}_{2} \quad 79 \%\right.$ 

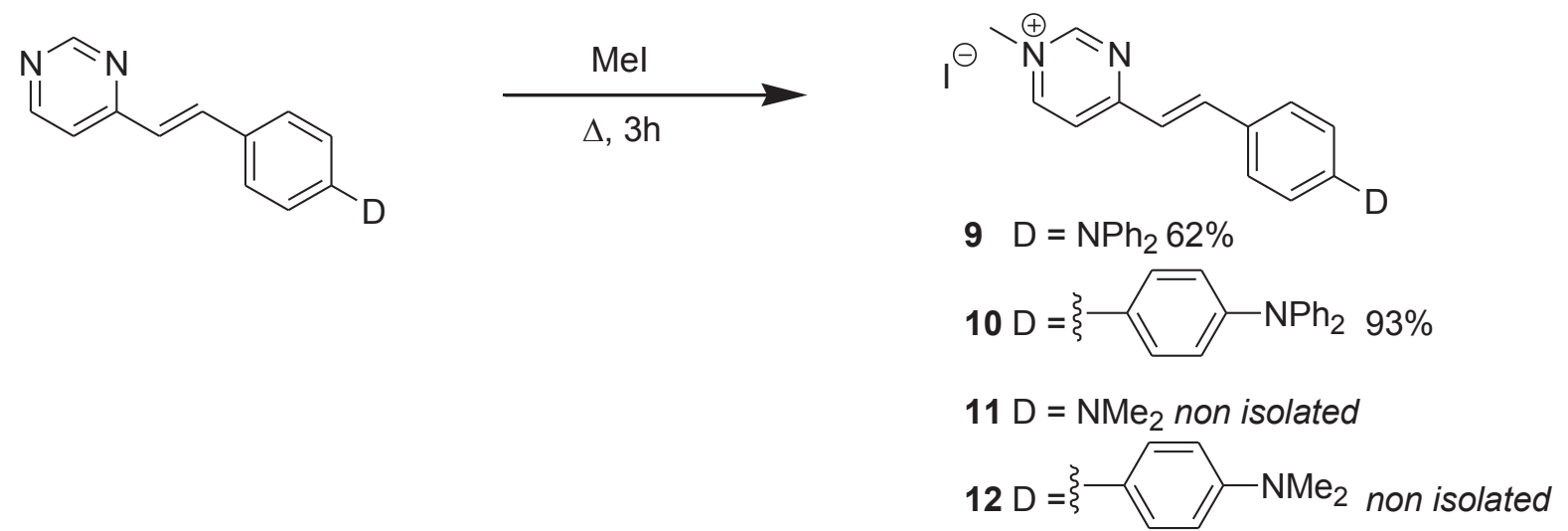

\section{Scheme}

D

$\Delta, 3 \mathrm{~h}$

$9 \mathrm{D}=\mathrm{NPh}_{2} 62 \%$

$10 \mathrm{D}=\xi-\mathrm{NPh}_{2} \mathrm{93} \%$

$11 \mathrm{D}=\mathrm{NMe}_{2}$ non isolated

$12 \mathrm{D}=-\mathrm{NMe}_{2}$ non isolated 


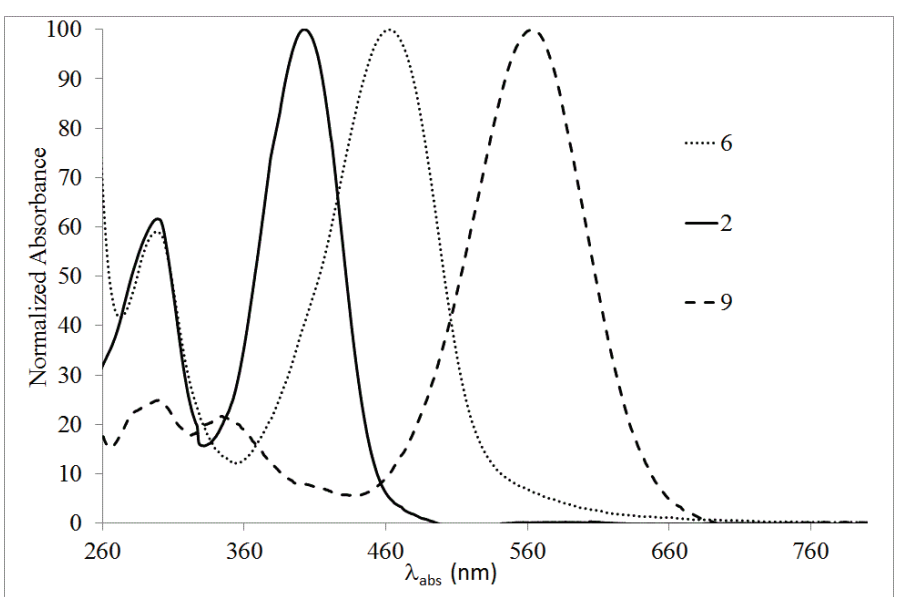




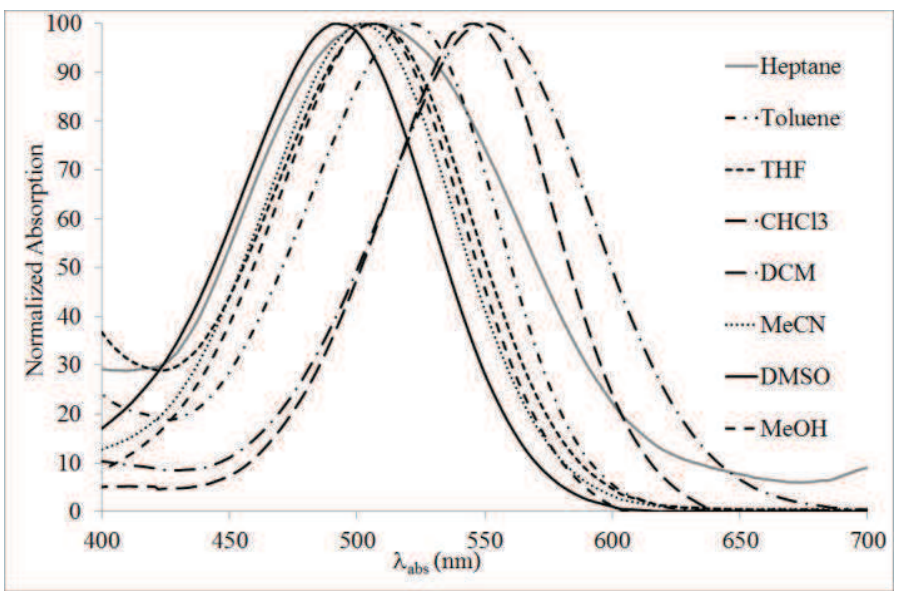



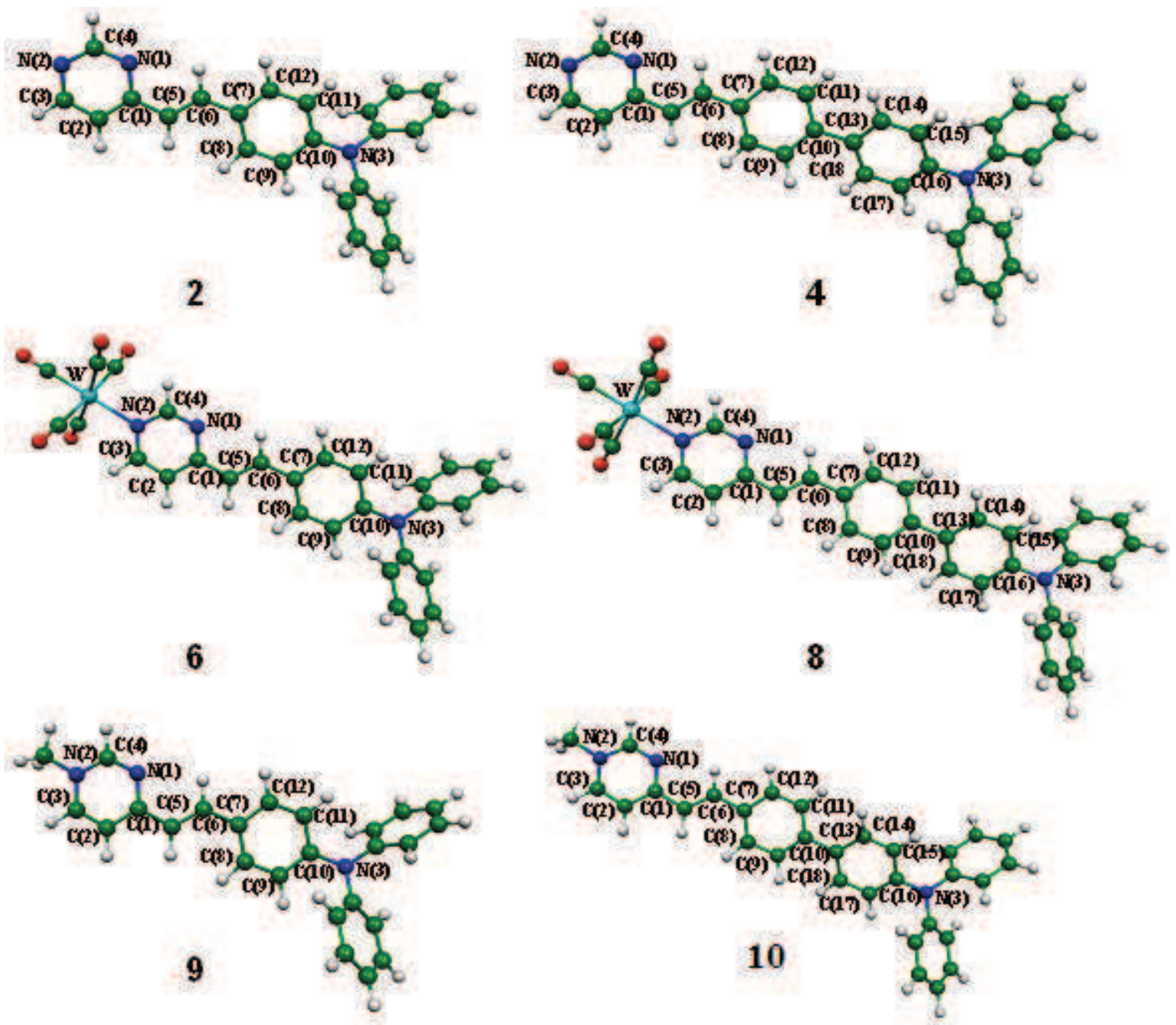

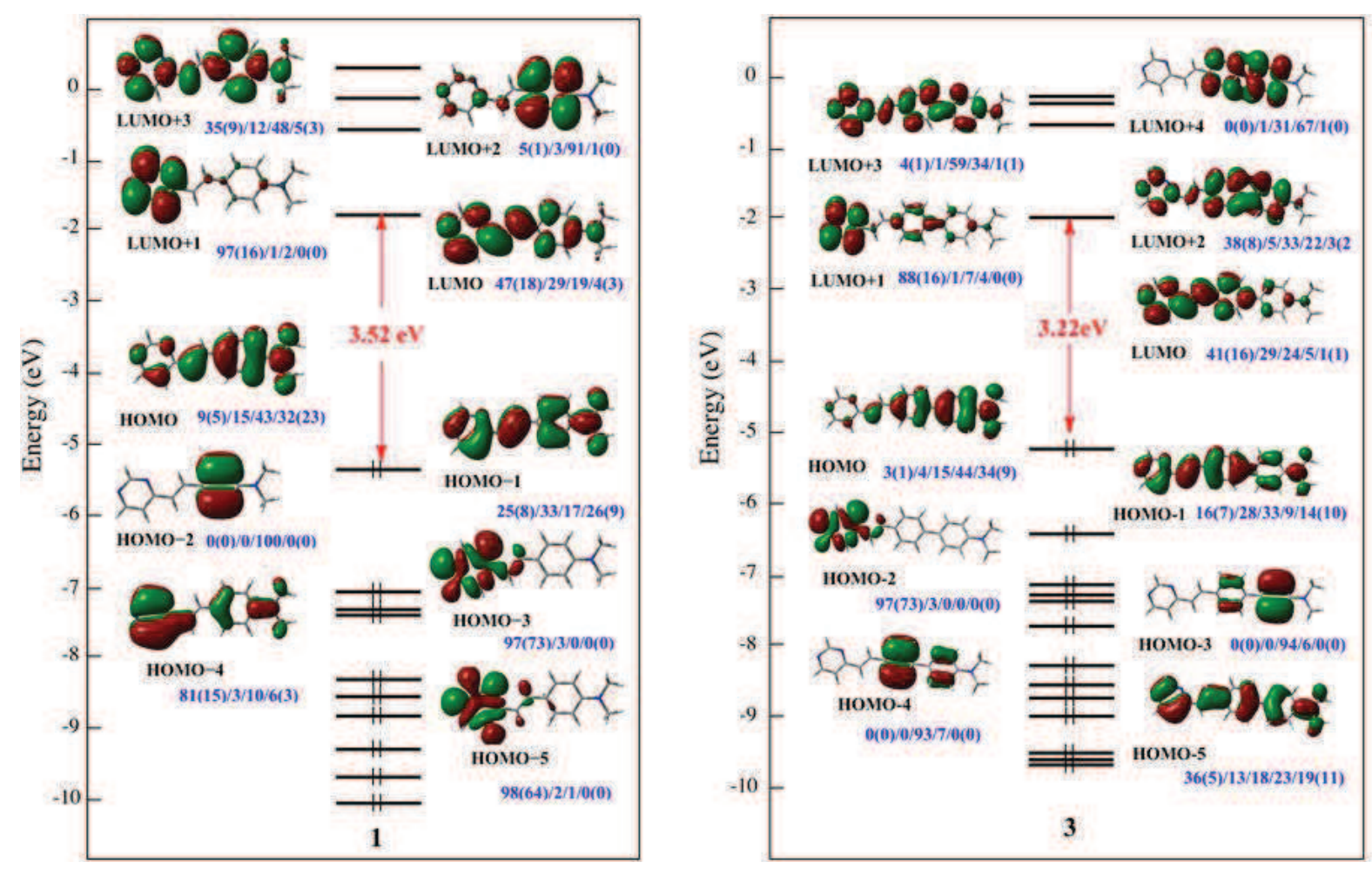